\title{
Economic Appraisal of Small and Medium Scale Poultry Egg Production in Ife and Ilesha Metropolis, Osun State, Nigeria.
}

\author{
Busari Ahmed Olugbenga*, Okanlawon Islamiat Nike \\ Department of Agricultural Economics and Extension, Osun State University, Osogbo, Nigeria, College of Agriculture, Ejigbo Campus. Nigeria.
}

\section{A R T I C LE IN F O}

Article history:

Received 02 February 2015

Accepted 29 March 2015

Available online, ISSN: 2148-127X

Keywords:

Economic Appraisal

Poultry Egg Production

Budgetary Analysis

Gross Margin

Return on investment

${ }^{*}$ Corresponding Author:

E-mail: busariahmed2008@yahoo.com

\section{A B S T R A C T}

The study appraised the economic performance of small and medium scale poultry egg production in Ife and Ilesha metropolis, Osun State Nigeria. A purposive sampling was used to select one hundred and twenty poultry egg farmers, cluster sampling was used to select areas where small and medium scale were concentrated in the study area then sixty (60) small scale and sixty (60) medium scale were randomly selected to form the population of the study. Data were collected through structured interview schedule. Descriptive statistics such as means and percentages were employed for budgetary analysis and economic performance. The ordinary least square was used to determine the significant variables influencing the gross margin of poultry egg farmers at different levels of scale of production. The study shows that the gross margin of small farms was $\$ 575.65$ while the gross margin of medium farms was $\$ 43672.62$. The total production cost of small and medium farms were 1480.25 and 29654.43 respectively. The results further reveal that costs of feed constituted the largest share of the total costs for the two categories of farm size. The amount spent on drug and feed were the only significant determining factors of revenue accruable to both categories of poultry egg farmers. Although, poultry egg production was profitable in the study area, the level of profit depended on the scale of operation.

\section{Introduction}

Poultry is a collective name given to a group of birds reared or hunted for useful purposes (Aja, 2007). They are domesticated birds kept for egg or meat production which include chickens (domestic fowls) turkeys, ducks and geese (Chukwu, 2010). Poultry is the quickest source of meat and its production process involves the least hazardous and arduous in relation to other livestock enterprise. Hence, increased poultry production is one of the surest and quickest ways of bridging the animal protein intake gap between developing countries of the world (Apantaku et al., 1998). The task of bridging this protein intake gap appears formidable in view of the present economic and technological constraints besetting our livestock industry (Apantaku et al., 1998). According to Bamiro et al., (2006), poultry egg production is one of the major sub-sectors in Nigerian agricultural industry which supply protein, lipids and vitamins of high zoological value to man. Poultry eggs, apart from supplying protein are also a good source of high energy nutrients. Egg production is the major index of performance of commercial layer producers and is very often useful for policy purposes.

Small scale poultry refers to those operations in which the farmers frequently have difficulty to obtain sufficient input to allow use of technical inputs available to medium and large scale farmers. small scale poultry are mostly found in the rural area where production input are difficult to obtain and marketing outlet are not well organized while medium scale poultry farms are usually found in the urban area as well as semi urban areas where there is access to adequate production facilities and marketing outlet (Adeyemo and Onikoyi, 2012). Small scale poultry eggs are made of farms having less than 1000 birds while medium scale are farms having between 1000 and less than 5000 birds (Omotosho and Oladele, 1998).

In Nigeria, human population is on the increase FAO (1992) while food production growth is on decline. This has brought about food shortage especially animal protein (Brown and Kane, 1994). This problem is mostly among children and adolescents (Brown and Reme, 1994).

Poultry egg is one of the most nutritious and most complete foods known to man and it provides the means by which rapid transformation of animal protein intake can be achieved (Muritala et al., 2004).

Despite the nutritive value of poultry meat and egg its production in the country is grossly inadequate as reflected by the wide gap between demand and supply of the products. This could be attributed with numerous problems that poultry farmers in Nigeria are facing. This problem includes low capital base, inefficient management, technical efficiency, economic inefficiency, disease and parasite and poor housing (Alabi, 2002). High cost of feed, poor quality of day old chick, inadequate 
extension and training facilities are also problems faced by poultry farmers (Bamgbose et al., 1998). The poultry production capacities of farm has to increase rapidly to be able to meet up with the increasing demand, and for this to be achieve, the present level of production must be improved upon. This study appraised economically, small and medium scale poultry egg production in the study area.

\section{Materials and Methods}

The study was conducted in Ife and Ilesha metropolis of Osun state, Nigeria. Both areas are made up of rural, semi- urban and urban settings with high concentration of small and medium scale poultry egg farmers.

Data used in this study were obtained from primary sources. The data were collected with the aid of structured interview schedule administered to poultry egg farmers. The interview schedule was structured to collect information on socio- economic, characteristics of poultry farmers and economic information on poultry egg production. The data was aggregated for statistical analysis.

Purposive random sampling technique was used to select two areas for the study, cluster sampling was used to select area with the highest concentration of poultry egg farmers, therafter, simple random sampling was used to select sixty (60) poultry egg farmers from each from Ife and Ilesha metropolis, making a total of one hundred and twenty (120) poultry egg farmers as the sample for the study.

Data in this study was analyzed with both descriptive and inferential statistics. The descriptive statistics that was employed include means and percentages while the inferential statistics that was utilized are budgetary analysis and linear ordinary least squares regression techniques. Budgetary technique was used to determine the economic performance of poultry egg producers by scale while linear ordinary least square regression technique was used to determine the significant variables influencing the gross margin of poultry egg farmers at different scale levels. Depreciation of fixed asset was estimated using the straight line method. The gross margin (GM) is estimated from

\section{GM=TR-TVC}

GM represents gross margin (TR - TVC), TVC represents total variable cost, TR represents total revenue and TFC represents the total fixed cost. Following the method employed by Oladebo and Ojo (2012) economic ratios employed to measure economic performance of the two groups of farms were: Rate of return on investment (ROI), operating ratio (OR), fixed asset turn over (FAT) and total asset turn over (TAT). They are analyzed follows:

1. Rate of return on investment (ROI) shows the amount gained on every naira ( $\mathrm{N})$ invested, measured as:

$$
\mathrm{ROI}=\mathrm{E} / \mathrm{C} \text { X } 100
$$

Where, E represents the profit before tax ( and C represents the total cost (A).

$$
\begin{aligned}
& \text { Operating ratio }(\mathrm{OR})=\frac{\text { Total Operating Expenses }}{\text { Net Sales }(\aleph)} \\
& \text { Fixed assets turnover }\left(\text { FAT) }=\frac{\text { Total Sales }(\mathbb{N})}{\text { Fixed assets }(\mathbb{N})}\right. \\
& \text { Total assets turnover }\left(\text { TAT) }=\frac{\text { Total sales }(\AA)}{\text { Total assets }(\AA)}\right.
\end{aligned}
$$

The relationship between the factors involved in cost and gross margin obtained from poultry egg production was investigated by the use of regression technique of analysis. The model is expressed as:

$$
\mathrm{Y}=\mathrm{f}\left(\mathrm{X}_{1}, \mathrm{X}_{2}, \mathrm{X}_{3}, \mathrm{X}_{4}, \mathrm{X}_{5}, \mathrm{X}_{6} \text {, et }\right)
$$

Where, $Y$ represents the gross margin of the poultry egg farmer producers (

$\mathrm{X}_{1}$ represent the amount of feed $(\mathrm{kg})$

$\mathrm{X}_{2}$ represents the cost of water (

$\mathrm{X}_{3}$ represents veterinary services ( $)$

$\mathrm{X}_{4}$ represents the amount of labour (man days)

$\mathrm{X}_{5}$ represents electricity cost ( $\left.\mathrm{N}\right)$;

$\mathrm{X}_{6}$ represents the costs of purchase of day old chicks (

$e_{t}$ represents the stochastic error term.

\section{Results and Discussion}

\section{Budgetary Analysis}

Table 1 shows the cost component of an average poultry egg farmer for the two categories of farms. The results indicated that an average poultry egg farmer invested about 1480.25 and 29694.43 as total costs of production for small and medium scale farms, respectively. These included costs of purchase of feed, cost of water, cost of drugs/ veterinary services, cost of chicks, cost of labour, cost of electricity and other necessary materials. The cost of feed for the two categories of farms constituted the largest share of the cost (about 72.12 and $40.31 \%$ for small and medium scale farms, respectively). These results support the findings of Yusuf and Malomo (2007) and Oladeebo and Ojo ( 2012) that feed cost is the major important cost item associated with poultry egg production probably due to increase in cost of maize, groundnut cake, soya bean meal and the attendant scarcity of wheat plus corn offal (Okafor et al., 2006). This was followed by cost of drugs/veterinary services for small scale poultry egg farmers (3.42\%), electricity costs for medium scale poultry egg farmers (about $15.20 \%$ ) while for small scale was $7.25 \%$, stock cost for small poultry egg farmers was $20.70 \%$ and for medium scale was $10.95 \%$, labour cost for small scale was 2.26 and for medium scale was $6.99 \%$ and water cost for small scale was $0.92 \%$ and for medium scale was $4.37 \%$.

Table 1 indicates that total revenue of $\$ 1945$ was earned by an average small poultry egg farmer and about ¥51611.80 was earned by an average medium scale poultry egg farmer, respectively. The analysis further shows that the net farm income received by an average small poultry farmers was about $¥ 464.75$ and \$21957.327 was received by an average medium scale poultry egg farmer, respectively. 
Table 1 Annual cost and return analysis per poultry egg farmer*

\begin{tabular}{|c|c|c|c|c|c|}
\hline $\mathrm{S} / \mathrm{N}$ & Item & Small & Scale & Medium & Scale \\
\hline $\mathrm{A}$ & Revenue (TR) & 1945 & & 51611.80 & \\
\hline \multirow[t]{8}{*}{ B } & Variable Costs & \multicolumn{2}{|c|}{$\%$ of TVC\% } & \multicolumn{2}{|c|}{ of TVC } \\
\hline & Cost of feed & 988.20 & 72.17 & 3200.08 & 40.31 \\
\hline & Cost of stock & 283.50 & 20.70 & 869.60 & 10.95 \\
\hline & Cost of drugs/vet & 46.85 & 3.42 & 762.80 & 9.61 \\
\hline & Labour cost & 30.95 & 2.26 & 555.00 & 6.99 \\
\hline & Cost of water & 12.60 & 0.92 & 348.20 & 4.39 \\
\hline & Electricity cost & 7.25 & 0.53 & 1206.80 & 15.20 \\
\hline & Tax & - & - & 996.70 & 12.55 \\
\hline $\mathrm{C}$ & Total Variable Cost & 1369.35 & 100 & 7939.18 & 100 \\
\hline $\mathrm{D}$ & GrossMargin (TR -TVC) & 575.65 & & 43672.62 & \\
\hline \multirow[t]{2}{*}{$\mathrm{E}$} & Fixed Cost & & & & \\
\hline & Depreciation Cost & 110.90 & & 21715.25 & \\
\hline $\mathrm{F}$ & Total production cost & 1480.25 & & 29654.43 & \\
\hline G & Net farm income & 464.75 & & 21957.37 & \\
\hline
\end{tabular}

*Field Survey 2014

The budgetary analysis for the small and medium scale poultry egg producers revealed that poultry egg production was profitable and the level of performance depends on level of scale where farmers face same market conditions. The results obtained compared favorably with the findings of Okafor et al. (2006), Amos (2006), Yusuf and Malomo (2007) and Oladebo and Ojo (2012).

\section{Economic Performance Analysis}

Table 2 shows the performance ratios of the two farm types. The results show that medium scale poultry egg farmers had higher return on investment (ROI) than their small scale poultry farmers. The small scale poultry egg farmers obtained 23.19 return on a naira invested while the medium scale poultry farmers obtained $\$ 78.43$ return on naira invested. This is an indication of the fact that medium scale poultry egg farmers were able to minimize operating expense better than their small scale poultry egg farmers probably due to economies of size. The values 0.86 obtained for operating ratios for small scale poultry egg farmers and 0.17 for medium scale poultry egg farmers respectively. This table also shows that fixed asset turnover is 6.87 for small scale poultry egg farmers and 2.65 for medium scale poultry egg farmers, the total assets turnover is 1.35 for small scale poultry egg farmer and 1.90 for medium scale poultry egg farmers. Thus, in terms of net farm income, medium scale poultry egg farmers performed better than the small scale poultry egg farmers.

Result of regression Analysis for Small and Medium Scale Poultry Egg Farmers

The regression results for small and medium scale poultry egg farmers are presented in Table 3 and 4 respectively. The results show that there was goodness of fit of the production function based on their significant Fvalues. Table 3 shows that 58 percent of the adjusted variability in the gross margin obtained by small scale poultry egg farmers was explained by the included explanatory variables in comparison with 68 percent of the adjusted variability in the gross margin obtained by their medium scale counterparts in (Table 4).

Table 2 Comparison of performance ratios for the two farms*

\begin{tabular}{l|cc}
\hline \multicolumn{1}{c|}{ Ratio } & Small Scale & Medium Scale \\
\hline ROI & 23.19 & 78.43 \\
OR & 0.86 & 0.17 \\
FAT & 16.87 & 2.65 \\
TAT & 1.35 & 1.90 \\
\hline
\end{tabular}

*Field Survey, 2014. ROI is rate of return on investment, OR is operating ratio, FAT is fixed asset turnover, TAT is total asset turnover.

Table 3 Regression results for small scale poultry egg farmers*

\begin{tabular}{l|rc}
\hline \multicolumn{1}{c|}{ Variable } & Coefficient & \multicolumn{1}{c}{ t-value } \\
\hline Constant & -2569.75 & -0.3981 \\
Amount of feed $\left(\mathrm{X}_{1}\right)$ & $4.3651 * * *$ & $5.652^{*}$ \\
Cost of water $\left(\mathrm{X}_{2}\right)$ & -336.35 & -0.318 \\
Cost of drug $\left(\mathrm{X}_{3}\right)$ & $-7.938 * * *$ & $6.772 *$ \\
Cost of labour $\left(\mathrm{X}_{4}\right)$ & -0.716 & -0.777 \\
Electricity cost $\left(\mathrm{X}_{5}\right)$ & 19.020 & 0.56 \\
Cost chicks $\left(\mathrm{X}_{6}\right)$ & 0.163 & 0.892 \\
\hline *Field Survey, 2014; $\mathrm{R}^{2}=0.671$, Adjusted $\mathrm{R}^{2}=0.581, \mathrm{~F}=17.223$, \\
Significant at 5\%
\end{tabular}

Table 4 Regresion result for medium scale poultry egg farmers*

\begin{tabular}{l|rc}
\hline \multicolumn{1}{c|}{ Variable } & Coefficient & t-value \\
\hline Constant & -5376.77 & -1.474 \\
Amount of feed $\left(\mathrm{X}_{1}\right)$ & $-3.213 * * *$ & $7.632 *$ \\
Cost of water $\left(\mathrm{X}_{2}\right)$ & -3.321 & -0.328 \\
Cost of drug $\left(\mathrm{X}_{3}\right)$ & $7.538 * * *$ & $5.762 *$ \\
Cost of labour $\left(\mathrm{X}_{4}\right)$ & -0.716 & -0.777 \\
Electricity cost $\left(\mathrm{X}_{5}\right)$ & 1.912 & 0.562 \\
Cost of chick $\left(\mathrm{X}_{6}\right)$ & 0.186 & 0.792 \\
\hline *Field survey 2014, $\mathrm{R}^{2}=0.771$, Adjusted $\mathrm{R}^{2}=0.681, \mathrm{~F}=19.323$, \\
Significant at 5\%.
\end{tabular}


The coefficients of cost of drug and cost of feed are significant at 5 percent level for small and medium scale poultry egg farmers. Cost of drug had negative coefficient for small scale poultry egg farmers as compared with positive coefficient obtained for their medium scale counterparts. The implication of the negative coefficient is that the average cost expended on drug per bird for small scale poultry egg farmers will be lower than their medium scale counterparts.

Similarly, cost of feed had positive coefficient for small scale poultry egg farmers as compared with negative coefficient obtained for their medium scale counterparts. The implication of the negative coefficient is that the average cost expended on feed per bird for small scale poultry egg farmers will be higher than their medium scale counterparts.

This study reveals that the amount spent on feed and drug are the major determinants of gross margin accruable to both categories of poultry egg farmers in the study area. The result of regression analysis is in line with the findings of Amos (2006) and Oladebo and Ojo (2012).

\section{Conclusions}

The study evaluated the economic performance of small and medium scale poultry egg farmers in the study area. The result of data analysis shows that poultry egg production is profitable in the study area, but the level of profit depends on the scale of production. Medium scale poultry egg producers were observed to have higher profit than their small scale counterparts. The study also revealed that the amount spent on drug and cost of feed was significant determinant of gross margin accruable to poultry egg farmers in the study area. Based on this the study recommended that policy focus should be geared towards how small scale poultry egg farmers will transform their scale of operation in order to enjoy the benefits of economies of scale and thereby derive maximum profit from poultry egg farming while meeting the increasing demand for poultry eggs.

\section{References}

Adejoro S O 1991. Strategies for Animal Health Care Management in the Tropics. World Poul. Misset. 7(4): 84-85

Afolabi A Ojo SO 2000. Economic Analysis of Replacing the Fish meal component in Broiler starter Mash with Gliricidia Sepium. Animal Options Book of Proceeding. Ed. By S.N. Ukachuwku et al. African. Farming January. Jan/Feb (1998), page: 4 .

Ajibefun IA, Daramola AG. 1999. Measuring and sources of Technical Inefficiency in Poultry Egg Production in Ondo State. J. of Rural Econ. Develop. 4: 85-94.

Alabi RA, Osifo AA. 2005. Population Density and Technical Efficiency of Cocoa Based Agroforestry.

Amos TT. 2006. Analysis of Backyard Poultry Production in Ondo State, Nig. Int. J. of Poul. Sci. 5:247-250
Apantaku SO, Oloruntoba A, Fakoya EO. 2003. Farmers' involvement in agricultural problems identification and prioritization in Ogun State Nigeria' South African J. of Agric, Ext. 32: 45-59 .

Apantaku SO, Omotayo AM, Oyesola AB. 1998. Poultry farmers' willingness to: participate in Nigerian agricultural insurance scheme in Ogun State, Nigeria. (Editors).

Bamiro A. 2006. Vertical Integration and Technical Efficiency in Poultry (Egg) Industry in Ogun and Oyo States, Nig. Int. J. of Poult. Sci. 5: 1164-1171.

Biggs SD. 1989. Resource-poor farmers' participation in Research: A synthesis of experiences from nine national agricultural research systems. OFCOR Comparative Study Paper No. 3. The Hague: ISNAR. 1-4.

Central Bank of Nigeria, 1999. Annual Report and statement of Accounts. CBN Publications.

Central Bank of Nigeria. 2004. Annual Report and statement of Accounts. CBN Publications.

FAO. 1992. Poultry in the 21st Century: avian influenza and beyond. Proceedings of the International Poultry Conference, held 5-7 November 2007, Bangkok, Thailand. Edited by O Thieme and D Pilling. FAO Animal Production and Health Proceedings, No. 9. Rome.1.

Folorunsho OR, Onibi GE. 2005. Assessment of the Nutritional Quality of Eviscerated Waste from Selected Chicken Types. In Onibi GE, Agele SO, Adekunle VAJ (eds). 2005. Proceedings of the 1st Annual Conference on Developments in Agriculture and Biological Sciences. 27th April, 2005. School of Agriculture and Agricultural Technology, Federal University of Technology, Akure, Nigeria, pp:300.

Kelebemang GN. 2008. "Poultry and Rabbit Annual Report". Department of Animal Production. Ministry of Agriculture. Gaborone, Botswana.

Michael JD. 2001. PAS. Department of Animal Science University of Connecticut Storrs, CT 06269-4040

Niang TS, Jubrin S. 2001. Quarterly Newsletter of the Nigeria Agriculture Question and Answer ServiceVol.1 No. 3.

Oduguwa OO, Fanimo AO, Osinowo OA. 1998 Proceedings of the Silver Anniversary Conference, Nigerian Society for Animal Production. Gateway Hotel, Abeokuta. 21-26 March 1998, 542

Ojo SO, Afolabi JA. 2000. Economic Analysis of fowl egg. Nig. J.of Agric. Sc. 3:1

Okafor RM, Odii MACA, Emeyonu CA, Obih U. 2006. Profitability Analysis of PoultryProduction Imo State, Nigeria. In: Adepoju SO, Okuneye PA (eds). Proceedings of the 20th Annual National Conference of Technology and Agricultural Development in Nigeria. 18th-21stSept. (2000) Forestry Research Institute of Nigeria, Federal College of Forestry, Jos, Nigeria pp.392-397

Oluyemi JA, Robert FA. 1979. Management and Housing of Adult Birds in Poultry production in wet climate Page 49-10

Omotosho, O.A Ladele, AA 1988. Management Problems in Large Scale Poultry Business in Nigeria FARMAN J., pp: 3 and 2735. Poultry Annual Report(2000) Department of Animal Health and Production, Ministry of Agriculture. Gaborone,

Olabode JO, Ojo SO. 2012. Economic Appraisal Of Small and Medium Scale in Poultry Egg Production in Ogun State, Nigeria

Poultry Annual Report. 2001. Department of Animal Health and Production' 'Ministry Agricultural Gaborone, Botswana.

Yusuf SA, Malomo O. 2007.Technical Efficiency of Poultry Egg Production in Ogun A Data Envelopment Analysis (DEA) Approach. Int. J. Poul. Sc. 6: 622-629. 